\title{
INTEGRATED LAMINATED SHALY SAND ANALYSIS (LSSA) AND MONTE CARLO UNCERTAINTY PROBABILISTIC APPLIED FOR THE THIN LAMINATION RESERVOIR TOWARDS SIGNIFICANT NET PAY ADDITION
}

\author{
Frankstein Arphan ${ }^{1}$, Adi Gunawan ${ }^{1}$, Wien Lestari ${ }^{2}$, Widya Utama ${ }^{2}$ \\ ${ }^{1}$ Exploration Department, Pertamina Hulu Energi \\ ${ }^{2}$ Geophysical Engineering Department, Faculty of Civil, Planning and Earth Sciences, Insititut Teknologi Sepuluh \\ Nopember \\ e-mail : Franksteinarphan97@gmail.com
}

\begin{abstract}
Abstrak. Dalam beberapa tahun terakhir, evaluasi formasi dan analisis logging sumur telah berkembang dari pengukuran, akurasi dan penerapannya untuk menentukan kondisi bawah permukaan yang kompleks. Thin Bed Reservoir adalah salah satu analisis pemboran sumur yang kompleks dikarenakan kompleksitas kandungan tinggi mineral lempung dalam lapisan laminasi shaly-sand yang secara inheren mempengaruhi respons data log dalam bentuk nilai sinar gamma tinggi dan resistivitas rendah. Hal ini menyebabkan zona laminasi tipis sering diidentifikasi sebagai zona non-reservoir. Sementara itu, 30 - 40\% cadangan sumber daya minyak berasal dari lapisan thin bed reservoir. Melihat permasalahan dalam mendapatkan parameter petrofisika thin bed reservoir, penelitian ini berfokus pada pengoptimalan potensi lapisan tipis dengan mengevaluasi kembali analisis petrofisika, menerapkan metode Laminated Shally Sand Analysis dan Monte Carlo Uncertainty untuk menghitung distribusi parameter petrofisika dan memvalidasi parameter dengan Log Image. Metode laminated Shally Sand Analysis menerapkan Thomas Steiber Plot untuk memberikan distribusi serpihan dan porositas laminasi, sedangkan saturasi air dihitung menggunakan Persamaan Waxman Smith. Dari penelitian ini, sumur SSK memiliki potensi lapisan tipis pada $2521.45-2543.45 \mathrm{ft}$. Laminated Shally Sand Analysis juga mampu meningkatkan ketebalan netpay dengan kisaran 40,35\% berdasarkan probabilitas Monte Carlo.
\end{abstract}

Kata Kunci: Laminated Shally Sand Analysis; Monte Carlo Uncertainty; Thin Bed Reservoir

\begin{abstract}
In recent years, formation evaluation and well logging analysis have been evolving from its measurements, accuracy and applicability to determine tough downhole environments. Thin bed Reservoir is one of the most challenging well logging analysis due to the complexity of the high content of clay minerals in the shaly-sand lamination layer (thin bed) which inherently affects the log data response in the form of high gamma ray values and low resistivity. This causes the thin lamination zone is identified as a non-reservoir zone. Meanwhile, worldwide 30 to $40 \%$ of the oil in-place resources are confined within thin beds. Seeing the problem in the prediction of thin bed reservoirs, this research is focusing on Enhancing and developing thin bed potential by reevaluating petrophysical analysis, applying Laminated Shally Sand Analysis and Monte Carlo Uncertainty Probabilistic for calculating petrophysical parameter distribution and validating the parameter with Log Image. Laminated Shally Sand Analysis implements Thomas Steiber Plot in order to give laminated shale distribution and porosity, whereas the water saturation is calculated using Waxman Smith's Equation. From this research, well SSK has thin bed potential at $2521.45-2543.45 \mathrm{ft}$. Laminated Shally Sand Analysis also capable to improve thickness of netpay with the range of $40.35 \%$ based on probabilistic delivered from Monte Carlo.
\end{abstract}

Keywords: Laminated Shally Sand Analysis; Monte Carlo Uncertainty; Thin Bed Reservoir

\section{INTRODUCTION}

To find out the existence of petroleum, it is necessary to analyze the layer of the earth using Well logging. Well logging is the process of recording various physical, chemical, electrical, or other properties of the rock/fluid mixtures penetrated by drilling a borehole into the earth. Log data is used for qualitative and quantitative analysis and it give us information about rock formations in wells and the amount of petroleum reserves that can be obtained (Abdullatif dan Abdulraheem, 2013). 
Basically conventional logging tools have a vertical resolution of 1-4 $\mathrm{ft}$ while the thin bed layer has a thickness of $0.5 \mathrm{ft}$. Therefore, this thin layer cannot be recorded in the measurement of conventional logging. Meanwhile, worldwide 30 to $40 \%$ of the oil in-place resources are confined within thin beds (Tyagi dkk., 2008).

Fluid identification is an important factor in formation evaluation and is the main parameter in determining the development of an oil and gas field. The complexity of the high content of clay minerals in the shaly-sand lamination layer (thin bed) is accompanied by mineral clay distribution which inherently affects the log data response in the form of high gamma ray values and low resistivity (Brandsen, 2016). In a thin shaly-sand lamination area, the value of electrical conductivity shows a higher value so that a low resistivity value is obtained. This causes the thin lamination zone to be identified as a non-reservoir zone which is not expected to be an oil and gas potential that lead to misinterpretation in water saturation calculations (Olsen, 2016). Even though this layer has the potential to increase oil and gas reserves, other log data is needed to solve the thin bed problem .

Seeing the problem in the prediction of thin bed reservoirs, then further research is needed on the prediction of thin bed reservoir using Laminated Shally Sand Analysis and Monte Carlo Uncertainty Probabilistic. Laminated Shally Sand Analysis itself capables to resolve this problem where it implements resistivity separation to determine resistivity anisotrophy and Thomas Steiber Plot to give laminated shale distribution and porosity (Thomas dan Stieber, 1975). Furthermore, Monte Carlo is used as a distribution parameter between each petrophysical parameter. This research is focusing on Enhancing and developing thin bed potential by reevaluating petrophysical analysis.

\section{A. Thin Bed Reservoir}

Thin bed reservoir is a rock unit which is laminated with each other, has a thin distribution whose petrophic character is limited to the top and bottom with different petrophysical characteristic units (Baillie dan James-Romano, 2010). Thin beds have a thickness of $2.5 \mathrm{~cm}$ to 0.6 meters, where a thickness of 0.6 meters is considered a thin-bed cutoff because it is considered to be equivalent to the vertical resolution of the porosity log and log resistivity with the best resolution. In a thin shalysand lamination area, the value of electrical conductivity shows a higher value so that a low resistivity value is obtained. This causes the thin lamination zone to be identified as a non-reservoir zone which is not expected to be an oil and gas potential which causes misinterpretation in water saturation calculations. Even though this layer has the potential to increase oil and gas reserves, other log data is needed to solve the thin bed problem (Lalande, 2004). Thin beds can occur in all siliclastic depositional environments, with several depositional environments mostly composed of thin beds. Table 1 shows the depositional environment that allows Thin Beds to occur.

Table 1. Thin Bed Reservoir's Depositional Enviroment (Passey dkk., 2006)

\begin{tabular}{|c|c|c|}
\hline Depositional System & Thin-bed-prone & Not thin-bed-prone \\
\hline Deep-water & $\begin{array}{l}\text { Overbank/levee deposits } \\
\text { Distributary lobe } \\
\text { Channel margin } \\
\text { Hemipelagic }\end{array}$ & $\begin{array}{l}\text { Channel axis } \\
\text { Debrites (sandy or muddy) }\end{array}$ \\
\hline Beach/shoreface & $\begin{array}{l}\text { Lower shoreface } \\
\text { Distal lower shoreface }\end{array}$ & $\begin{array}{l}\text { Foreshore } \\
\text { Upper shoreface }\end{array}$ \\
\hline Deltaic & $\begin{array}{l}\text { Delta front } \\
\text { Prodelta }\end{array}$ & Stream-mouth bar \\
\hline Tidal/estuarine & $\begin{array}{l}\text { Sandy tidal channel } \\
\text { Intertidal sand flats }\end{array}$ & Subtidal \\
\hline Fluvial & $\begin{array}{l}\text { Point bars (meandering stream) } \\
\text { Levees } \\
\text { Terminal splay (overbank) }\end{array}$ & $\begin{array}{l}\text { Braided streams } \\
\text { Channel sands } \\
\text { Channel lag deposits } \\
\text { Fluvial bars } \\
\text { Alluvial fans }\end{array}$ \\
\hline Aeolian & $\begin{array}{l}\text { Interdune } \\
\text { Wind-rippled deposits }\end{array}$ & Cross-bedded dunes \\
\hline
\end{tabular}

\section{B. Laminated Shally Sand Analysis}

The Laminated Shally Sand Analysis suggests a multilayer sand-shale model. This analysis was based 
on the Thomas Steiber volumetric shale distribution and the tensor resistivity model (Thomas dan Stieber, 1975). Volume shale, porosity, and water saturation are the basic parameters to estimate sand layer resources. The volume of the shale is the most critical parameter, and controls the porosity and saturation calculcation. The Thomas Steiber model is used to define shale distribution (laminar, dispersed, or structural) from a bulk shale volume and total porosity. Independently, the tensor resistivity model is used to determine resistivity of sand and volume of laminar shale.

\section{B1. Resistivity Anisotropy}

The conventional resistivity measurements are dominated by conductive layers because these measurements are made horizontally to the formation (Ruhovets, 1990). The shale laminations are very conductive as compared to sand with gas or oil laminations. The result is highly conductive and indicates a poor zone. 3D Resistivity Tool provides measurements in both the horizontal ( $\mathrm{Rh}$ ) and the vertical (Rv) directions. It helps to resolve the resistivity anisotropy associated with the thinly laminated shale sand reservoir.

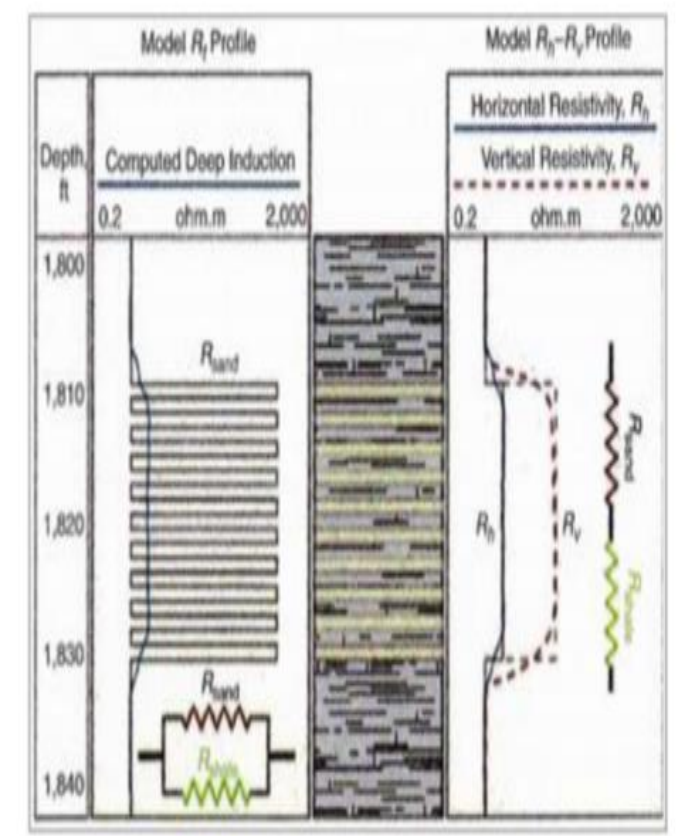

Figure 1 Resistivity Model in Thinly Laminated Reservoir (Anderson dkk., 2008)

$$
\begin{gathered}
R v=\sum_{n=1}^{n} L n \cdot R t \\
\frac{L}{R h}=\sum_{n=1}^{n} \frac{L n}{R t} \\
A=\frac{R v}{R h}
\end{gathered}
$$

If the $3 \mathrm{D}$ induction tool is not available, we can use the gamma ray log for differencing shale anisotropy from the thin laminated reservoirs(Asquith dan Krygowski, 2004). The resistivity of the sand can be calculated if we estimate the volume of shale of each point (Asquith dan Krygowski, 2004).

$$
\begin{aligned}
& V s h=\frac{G R-G R \min }{G R \max -G R \min } \\
& V s=1-V s h \\
& \frac{1}{\mathrm{Rh}}=\frac{V s}{R s}+\frac{V s h}{R s h} \\
& R v=V s . R s+V s h . R s h \\
& R s^{2} \cdot(R h . V s)+R s .\left(V s h^{2}+R h . V s-\right. \\
& R h . R v)+V s \cdot R s=0
\end{aligned}
$$

\section{B2. Thomas Steiber Model}

Thomas and Steiber provides a model to assess the possibility that porosity depends on shale volume and the configuration of the shale volume itself (Fadjarijanto dkk., 2018). This model is used to determine shale distribution and to recalculate porosity number. This approach can identify shale type using Vsh and PHI data as input. From this model we can determine shale distribution into laminated, structural, or dispersed.

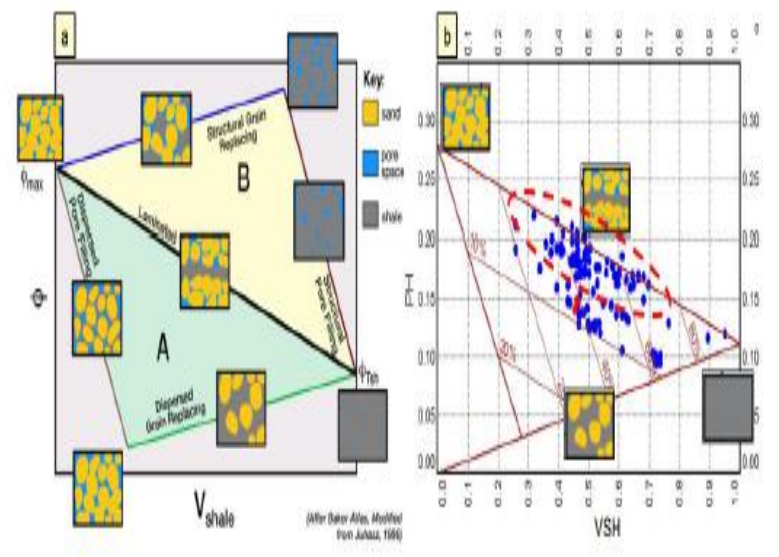

Figure 2. Shale Distibution on Thomas Steiber Plot 


\section{Monte Carlo Probabilistic}

Monte Carlo uses random number to calculate probability when the model is complex, nonlinear, or involves more than just a couple uncertain parameters. In this research, monte carlo is used to determine probability of each petrophysical parameter after thin bed analysis.

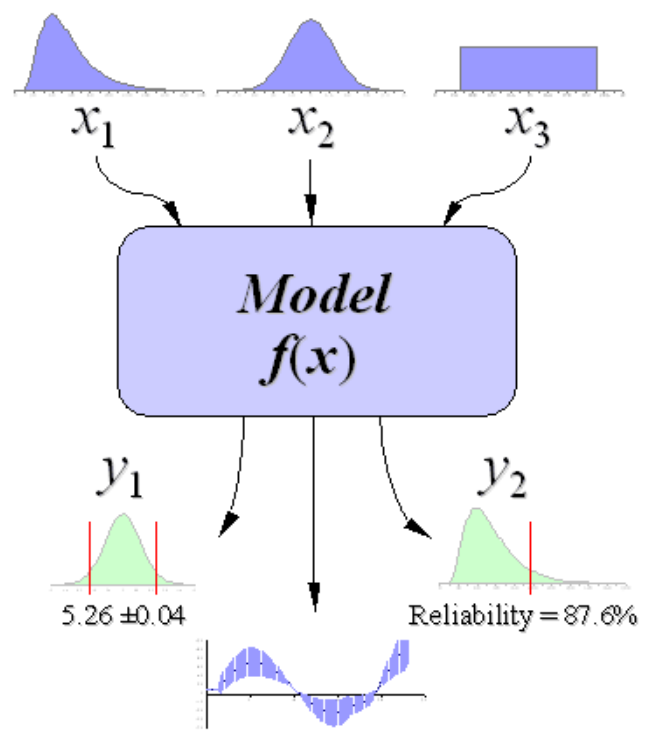

Figure 3. Workflow behind Monte Carlo

\section{METHODOLOGY}

The research is designed in several stages, which are illustrated in the flow diagram as shown below :

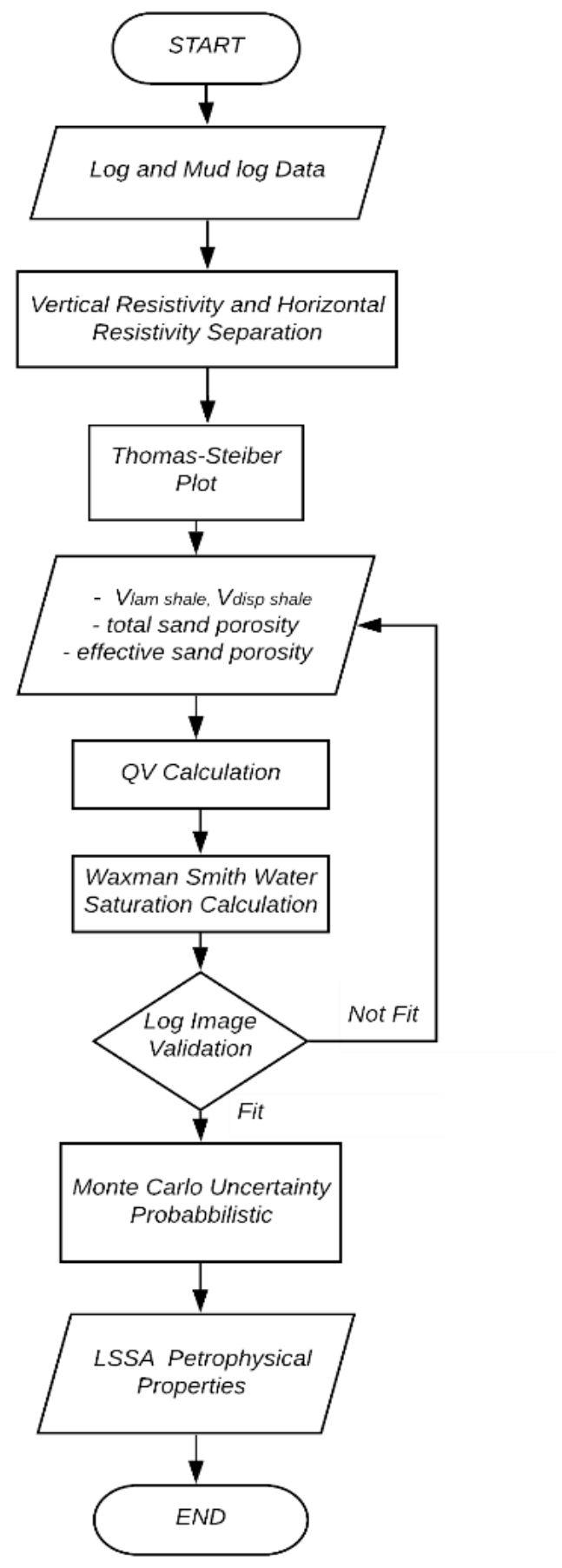

Figure 4. LSSA Petrophysics Workflow (Fadjarijanto dkk., 2018)

\section{A. Determination of Thin Bed Reservoir's Prospect Zone}

The determination of the zone of the prospect of the thin bed reservoir is based on the response of gamma ray values that do not fully show the clean 
sand zone, the porosity values do not intersect causing poor porosity readings, a sufficiently decreased resistivity value from the reservoirreadable response, and the DT value parameters that remain the same between the clean sand layer and the thin bed layer. In addition, the determination of these parameters is based on mudlog data which shows the increase in sandstone lithology, increased ROP values, and the emergence of oil / gas shows in mudlog data. Based on the above parameters, there are 1 prospect zones in well SSK at depth of 2521.45 $-2543.45 \mathrm{ft}$.

\section{B. Calculation of RW with Picket Plot}

As no core data available in this Well, Water Resistivity (RW) calculations are performed using picket plots in conventional calculations to obtain water saturation parameters. Cementation exponent $(\mathrm{m})$, tortuosity factor (a) and saturation exponent $(n)$ are also determined using Picket Plot by determining fully water saturated area.

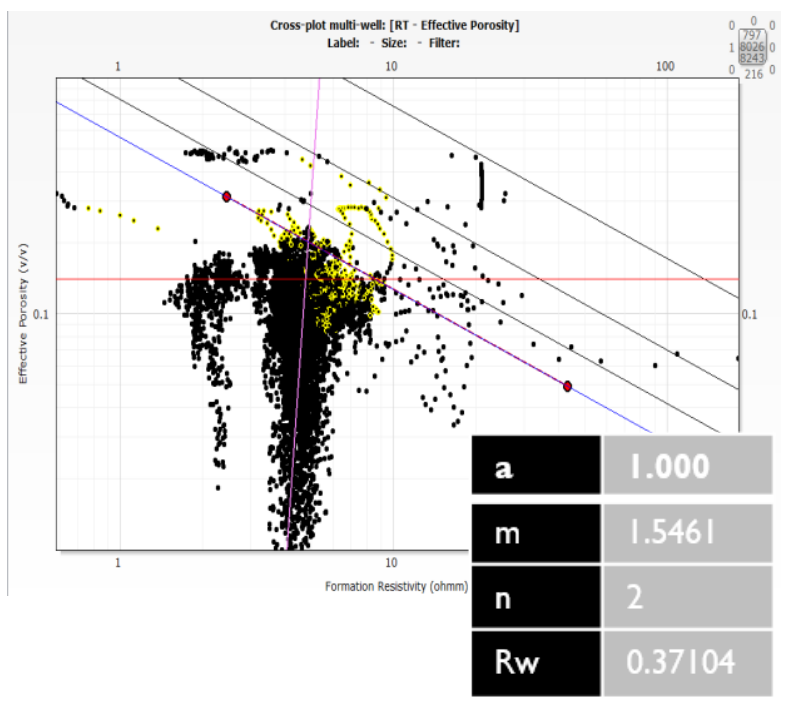

Figure 5. Parameters of Picket Plot Thin Bed Reservoir Well SSK

\section{LSSA Analysis}

LSSA analysis is done by calculating the vertical resistivity from horizontal resistivity, determining shale distribution using thomas steiber plot and plotting the graph of resistivity distribution to see the distribution of the distribution of resistivity values to improve the laminated shale resistivity value based on the resistivity distribution value in order to improve the previous low resistivity response value. Vertical resistivity separation in figure 6 shows there are some slight increasement in resistivity value, with a higher anistrophy compare with the background anisotrophy. This anisothrophy could be an evidence of lamination on this interval.

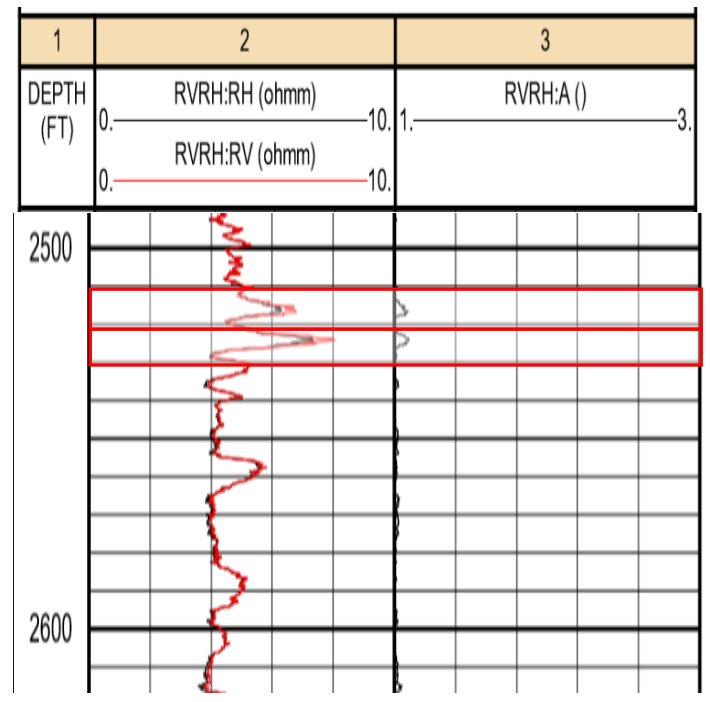

Figure 6. Vertical Resistivity Separation on Well SSK

Based on the analysis of Thomas Steiber in figure 7, it was found that the distribution of shale distribution was in the form of a laminated dominant with a dispersed and structural distribution where it falls in the center of the Thomas Steiber Plot.

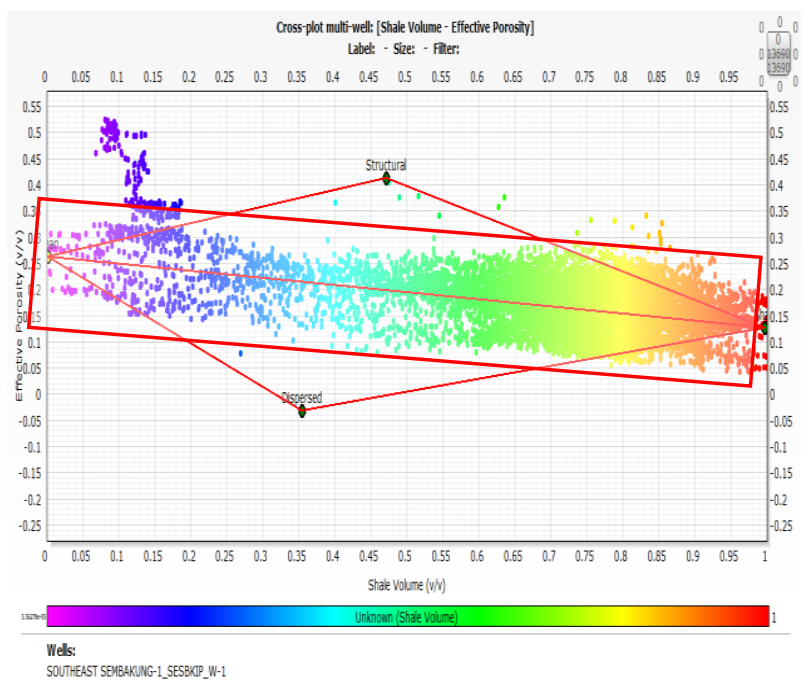

Figure 7. Thomas Steiber Plot on Well SSK 
Water Saturation is calculated $\mathrm{n}$ using Waxman Smith's Equation with parameters from table 2.

Table 2. Saturation Parameters

\begin{tabular}{|c|c|}
\hline Resistivity Mode & Waxman Smith \\
\hline Mud Filtrate Resistivity & $0.131 \mathrm{ohm} \cdot \mathrm{m}$ \\
\hline Temperature & $79 \mathrm{degF}$ \\
\hline WSQV (1/L) & 0.1 \\
\hline Maximum sand resistivity & 8.7122 ohm.m \\
\hline Saturation Model & Laminated \\
\hline
\end{tabular}

\section{RESULT AND DISCUSSIONS}

After LSSA analysis are taken, the shale volume distribution are obtained in the form of laminated, dispersed, and structural shale. From figure 8 , the LSSA output correlates with Thomas Steiber Plot, where the dominated shale volume type are laminated. This indicates the distribution and the shale volume of this interval is infulenced by laminated reservoir.

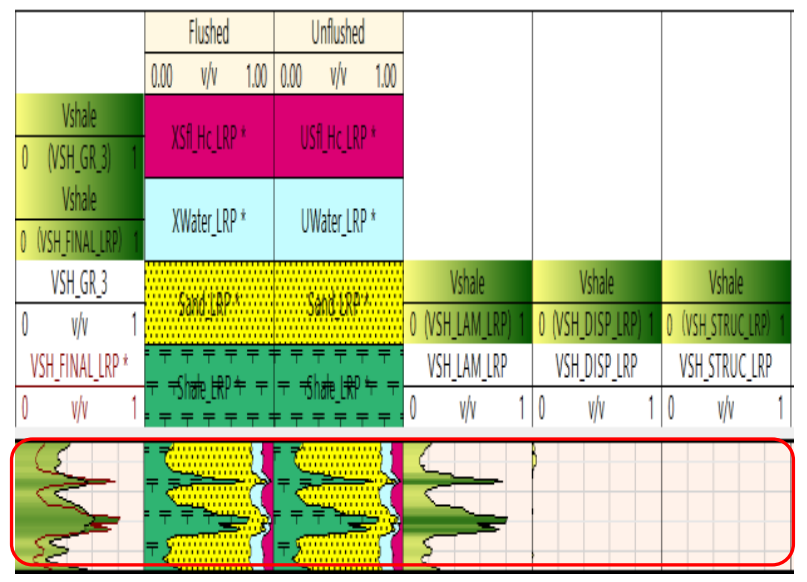

Figure 8. LSSA Output on Well SSK

Qualitative validation is done using log image. Mud log indicates oil show on this interval and log image also confirms the thin lamination layer. From figure 9, the log image shows a layer consisit of dark and bright colour that looks like a thin layered. The dark colour represents shale and bright represents sand.
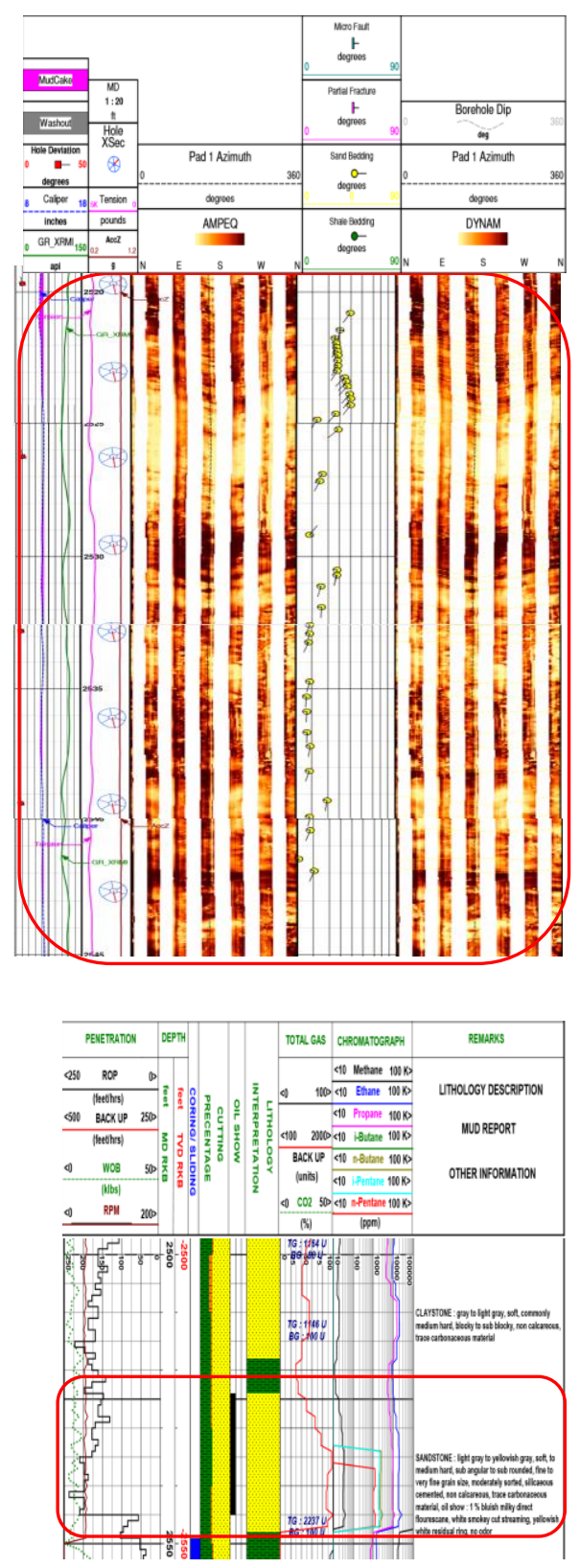

Figure 9. Mudlog and Log Image Validation

After monte carlo parameters are taken, the petrophysical parameter values are obtained in the form of a comparison between p10, p90, p50, mean, and conventional. It was found that the value after analysis LSSA had more optimistic values due to contributions from the thin bed reservoir compared with conventional based on the number of porosity, shale volume, water saturation and total net on p90 distribution as shown on table 3. 
Table 3. Petrophysical Parameter

\begin{tabular}{|c|c|c|c|c|c|}
\hline SSI & SSI & Net & $\begin{array}{c}\text { Av_Shale } \\
\text { Volume }\end{array}$ & Av_Porosity & $\begin{array}{c}\text { Av_Water } \\
\text { Saturation }\end{array}$ \\
\hline NON LSSA & NON LSSA & 13.751 & 0.448 & 0.142 & 0.767 \\
\hline \multirow{4}{*}{ ISSA } & LSSAP10 & 4.8 & 0.1981 & 0.1668 & 0.4555 \\
\cline { 2 - 6 } & ISSAP50 & 13 & 0.3346 & 0.1101 & 0.5189 \\
\cline { 2 - 6 } & ISSAPO & 18.3 & 0.3346 & 0.2487 & 0.5411 \\
\hline
\end{tabular}

\section{CLOSING}

\section{Conclusions and Recommendations}

Conclusions for this research as follow :

a. Laminated Shally Sand Analysis capables to determine shale distribution, porosity, resistivity of laminated sand, and laminated pay zone of Tabul Formation and Naintupo Formation based on validation from Mud log and log image

b. SSK has a thin bed potential at $2521.45-2543.45$ $\mathrm{ft}$.

c. Laminated Shally Sand Analysis capables to improve thickness of netpay with the range of $40.35 \%$ based on probabilistic delivered from Monte Carlo P90.

Recommendations for this research:

a. Make another resistivity model using another algorithm as a comparator to determine vertical resistivity

b. Approach the thin bed reservoir with another method such as Laminated reservoir analysis method to compare thin bed reservoir's petrophysical parameter.

\section{Acknowledgements}

The authors thank to Pertamina Hulu Energi for providing data and facility to conduct this research.

\section{REFERENCES}

Abdullatif, O. dan Abdulraheem, A. (2013), COMPARING HYDROCARBON VOLUME BETWEEN LSA
(LAMINATED SAND ANALYSIS) AND STANDARD TECHNIQUES IN LOW RESISTIVITY SANDSTONE RESERVOIRS, masters, King Fahd University of Petroleum and Minerals. Diambil dari https://eprints.kfupm.edu.sa/id/eprint/138928/.

Anderson, B., Barber, T., Leveridge, R., Bastia, R., Saxena, K. dan Tyagi, A.K. (2008), Triaxial Induction - A New Angle for an Old Measurement,.

Asquith, G. dan Krygowski, D. (2004), Basic Well Log Analysis, Second Edition. Diambil 7 Mei 2020, dari https://www.aapg.org/publications/specialpublications/books/details/articleid/4429/basicwell-log-analysis-second-edition.

Baillie, K.A. dan James-Romano, J. (2010), Identifying and Quantifying Thin Bedded Pay (TBP) (Part B): The Use of Dynamic Data to Evaluate Productivity Potential in Gas Reservoirs, Society of Petroleum Engineers, http://doi.org/10.2118/133535-MS.

Brandsen, H. (2016), Shale and Clay Part II. NTNU Lecture Notes: Petrophysics, Interpretation of Well Data, Advanced Course.

Fadjarijanto, A., Rachmadi, A., Setiawan, A.S., Praptono, A., Suriyo, K., Simatupang, M.H., Pakpahan, O., Costam, Y.R. dan Zakaria, Z.U. (2018), Three Petrophysics Techniques Applied for the Thin Lamination Reservoir: The Impact towards Significant Reserve Addition, Offshore Technology Conference, http://doi.org/10.4043/28412-MS.

Lalande, S. (2004), Accepted: 2004-0930T01:41:22ZArtwork Medium: electronicInterview Medium: electronic, Characterization of Thin-Bedded Reservoir in the Gulf of Mexico: An Integrated Approach., Texas A\&M University. Diambil dari https://oaktrust.library.tamu.edu/handle/1969.1/ 65.

Olsen, S.G. (2016), Improved Petrophysical Evaluation of a Thinly Bedded Oil and Gas Bearing Reservoir, Using Triaxial Resistivity and Nuclear Magnetic Resonance Well Logging Measurements, Diambil dari https://ntnuopen.ntnu.no/ntnuxmlui/handle/11250/2410738.

Passey, Q.R., Guzmán-Garcia, A.G. dan K. E. Dahlberg (2006), Petrophysical Evaluation of Hydrocarbon Pore-Thickness in Thinly Bedded Clastic Reservoirs, hal. 133-153. http://doi.org/AAPG Archie Series, No. 1, Front Matter: About the Authors, Acknowledgments, Table of Contents, Preface, Editor's Preface, by Q. R. Passey, K. E. Dahlberg, K. B. Sullivan, H. Yin, R. A. Brackett, Y. H. Xiao, and A. G. Guzmán-Garcia, Pages 133 - 153 from:AAPG 
Archie Series, No. 1: Petrophysical Evaluation of Hydrocarbon Pore-Thickness in Thinly Bedded Clastic Reservoirs, Edited by Ken DahlbergCopyright 2006 by The American Association of Petroleum Geologists. All rights reserved. 10.1306/1157796A13220.

Ruhovets, V. (1990), "A Log Analysis Technique For Evaluating Laminated Reservoirs In The Gulf Coast Area", The Log Analyst, Vol.31, No.05. Diambil dari https://www.onepetro.org/journal-paper/SPWLA1990-v31n5a2.

Thomas, E.C. dan Stieber, S.J. (1975), The Distribution Of Shale In Sandstones And Its Effect Upon Porosity, Society of Petrophysicists and Well-Log Analysts, Diambil dari https://www.onepetro.org/conferencepaper/SPWLA-1975-T.

Tyagi, A.K., Bastia, Dr.R. dan Das, Dr.M. (2008), Identification and Evaluation of the Thin Bedded Reservoir Potential in the East Coast Deep Water Basins of India, Diambil dari https://www.spgindia.org/2008/317.pdf. 